\title{
Teacher Leadership in Class on The Formation of School Values and Characters of School-Ages
}

\author{
Ratnawati Susanto ${ }^{1)}$, Harlinda Syofyan ${ }^{1)}$, Reza Rachmadtullah ${ }^{2)}$ \\ \{ratnawati@esaunggul.ac.id ${ }^{1}$, soflynda@esaunggul.ac.id ${ }^{1}$, rezarachmadtullaheza@gmail.com² ${ }^{2}$, \\ Universitas Esa Unggul, Jakarta. Indonesia ${ }^{1)}$ \\ Universitas PGRI Adi Buana, Surabaya Indonesia ${ }^{2)}$
}

\begin{abstract}
Children are human beings that are born in good condition, can be educated and educated. In the process of interacting with the environment, children learn to form identity through the building of values and character through the role of parents and continued in school. In reality there is a problem of learning and social behavior of elementary school children is quite apprehensive that culminate up to the legal problem. Quantitative research methods and data collection techniques through questionnaires was conducted to analyze the linkage of teacher leadership in the classroom and the pattern of guidance approach to the building of values and character of primary schoolage children. The results showed that the formation of values and character positively and significantly influenced by: (1) Leadership of teachers in the classroom. (2) Pattern approach to guidance, (3) Implementation of simultaneous teacher leadership in the classroom and pattern of guidance approach.
\end{abstract}

Keywords: teacher leadership, determining character values, Education

\section{Introduction}

Biological, psychological and emotional developments need to get adult mentoring and guidance so that the direction of development can take place in full. The development of the child as a whole will make the child has maturity in preparing himself through the stages of development in the process of the next stage of life. This maturity will be seen from the values raised in daily behavior and become part of the realization of its existence with the environment[1], [2]. The process of biological, psychological and emotional development of the child becomes the main responsibility of the family role, in this case is the parent. Parenting patterns are the foundation for the development of values in the child's psychological and emotional growth. The experience of the formation of values in the psychological and emotional growth of the child continues as the child enters school age The age of 6-12 years as the age of the child in entering the primary school education level is a very critical and fundamental period in maturing by the values established by the parents. So the role of primary school teachers as adults becomes the second strategic role after the parent role. The role of the teacher is to continue and as a companion parent role, not the role of replacing the parents. The realization of the strategic role of teachers in primary schools is how to conduct asset's values education as a child's life skills based on the psychological and emotional characteristics of primary school-aged children [1].

Previous research has found that there are fifty problems of student behavior at elementary school age, namely: (1) stealing behavior, (2) cruel behavior, (3) sexual activity 
behavior, (4) [truant behavior, (5) (9) misbehavior, (10) disobedient behavior, (11) hateful behavior, (12) anger behavior, (8) unstable behavior, (13) misbehavior, (17) selfish behavior, (18) quarreling behavior, (19) peer behavior, (20) behavior, (22) disdain behavior, (23) behavior easily affected, (24) cowardly behavior, (25) wetting behavior, (26) behavior of masturbation, (27) lazy behavior, (28) behavior of no attention, (29) unkempt behavior, (30) sullen behavior, (31) cowardly behavior, (32) p criticism, (35) behavior shy, (36) suspicious behavior, (37) smoking behavior, (38) behavior of stubbornness, (39) behavior impractical behavior, (41) behavior attracts people's attention, (42) malicious behavior, (43) tense behavior, (44) sluggish behavior, (45) unbearable thinking behavior, (46) complaining, (47) investigating behavior, (48) intrusive behaviors, (49) imaginary behavior, (50) whispering behavior [3]. Behavioral problems are classified in groups of learning and social habits [4]. According to Darwis Abu, [5] who found the tendency of primary school-age behavior for rationalization or to justify, hostility, self-punishment when feeling anxiety or uncomfortable mood, take a refresher or hide away attitude when it is frightening, conformity or selfsustaining action in case of disappointment to others, is cynical in order to escape from incompetence.

The teacher holds a key role in the school, a second environment, a formal educational institution that also serves as a strategic gateway for mentoring the psychological and emotional development of primary school children. Primary school-age children need teacher demands, guidance and help in guiding their psychological and emotional development. It takes maturity and maturity of teachers to play a role in asset value's education for children. The interaction of teachers with primary school-aged children takes place intently in the process of learning in the classroom. The classroom teacher system in the primary school education system is very supportive for teachers to play their leadership roles in the classroom. Teacher leadership in the classroom becomes the foundation for the application of character education that prioritizes the values of life for elementary school - aged children.

Leaders are identified with the level of ability to influence members to achieve a goal. Leadership is a pattern of discipline. Understanding leadership is defined as the beginning of a structure (Leadership as the initiation of structure) [6] . Leadership is a way of giving meaning to the vision and realizing values so as to create a conducive environment for achieving the goal [7]. Within the scope of the school organization, teacher leadership is linked to the scope of work, which is identical to the classroom environment. Teacher leadership in a classroom environment is not limited by the understanding that the class is just a room with four walls where the learning interaction takes place. The teacher's understanding of the class should be in the broader sense, which places the role and function of the teacher as the leader in the class.Teacher leadership is defined as: "Teacher's leadership is the process by which teachers, individuals or collectively, influence their colleagues, principals, and other members of the student learning and achievement. Such team leadership work involves three intentional development foci: individual development, collaboration or team development, and organizational development. " [8]. It can be interpreted that teacher leadership is the process by which teachers, individually or collectively, influence colleagues, principals, and other school-community members to improve teaching and learning practices with the aim of improving student learning and achievement. Such team leadership work involves three deliberate developmental focuses: individual development, collaboration or team development, and organizational development. 


\section{Method}

The population and sample were done by saturated sampling technique. The technique is done to elementary school which is in the subdistrict of Jakarta area which is willing to become respondent. Sample size using solving formula. Data collection techniques were conducted using questionnaires to measure teacher leadership variables in the classroom, the guidance approach pattern and value, and character formation. The questionnaire used is a 2option scale with a choice of yes and no answers, with a score of 1 for yes and 0 for not. Data analysis technique using parametric analysis and data processing using ms excel and SPSS version 23: (1) instrument test analysis (product moment correlation and alpha Cronbach); (2) requirement test analysis (regression equation test, normality test data with liliefors and homogeneity test with test-brittle); and (3) hypothesis test with t-test.

\section{Results and Discussions}

\subsection{Hypothesis Testing}

First Is there a linkage of teacher leadership in the classroom to the building of the value and character of the students? The linkage of teacher leadership in the class to the building of the value and character of the students is shown by the correlation strength or correlation level $\mathrm{rX}_{1} \mathrm{Y}=0.688$ (strong relationship). Test the significance of correlation coefficient with tct $=$ 2.018. Price ttabel with $\mathrm{dk}=99$ and significance level $\alpha=0,05$ is with value equal to 1,664 and at $\alpha=0,01$ obtained value equal to 2,370. Since thitung $=2.018>$ ttable at $\alpha=0.05$ is 1.664 then $\mathrm{H}_{0}$ is rejected and $\mathrm{H} 1$ is received, meaning there is significant correlation between teacher leadership in class with building value and character in student. While the coefficient of determination $\left(\mathrm{R}^{2}\right)=\left(\mathrm{r} \mathrm{X}_{1} \mathrm{Y}\right)^{2}=0.473$, which means there is a contribution of $47.3 \%$ teacher leadership in the class on the building of the value and character of the students and the rest of $52.7 \%$ is determined by other factors not studied in this research. So it can be concluded that the leadership of teachers in the classroom needs to be strengthened in order to give effect to increase the building of value and character of students.

\subsection{Second Hypothesis Testing}

Is there a correlation between the pattern of guidance approach to the building of the value and character of the students? The correlation pattern of guidance approach toward the building of the value and character of the students is shown by the correlation strength or correlation level $\mathrm{rX}_{2} \mathrm{Y}=0.799$ (very strong relationship) Test significance correlation coefficient with tcount $=3.028$. Price ttabel with $\mathrm{dk}=99$ and significance level $\alpha=0,05$ is with value equal to 1,664 and at $\alpha=0,01$ obtained value equal to 2,370. Since thitung $=$ 2.018> ttable at $\alpha=0.05$ is 1.664 then $\mathrm{H}_{0}$ is rejected and $\mathrm{H}_{1}$ is received, meaning there is a significant correlation between teacher leadership in the class with the formation of values and character of the students. While the coefficient of determination $\left(\mathrm{R}^{2}\right)=\left(\mathrm{r} \mathrm{X}_{1} \mathrm{Y}\right)^{2}=0.639$, which means there is a contribution of $63.9 \%$ pattern guidance approach to value and character of the students and the rest of $36.1 \%$ is determined by other factors not studied in research this. Then it can be concluded that the pattern of guidance approaches need to be strengthened in order to give effect to increase the building of value and character of students. 


\subsection{Third Hypothesis Testing}

Is there a simultaneous linkage of teacher leadership in the classroom and the guidance approach to the formation of the value and character of the students? The simultaneous linkage of teacher leadership in the classroom and the pattern of guidance approach toward the building of the value and character of the students is shown by the correlation strength or correlation level $\mathrm{rX}_{1} \mathrm{X}_{2} \mathrm{Y}=0.759$ (very strong relationship) Test significance of correlation coefficient with $t_{c t}=1.984$ and 1.659. Price t-table with $\mathrm{dk}=98$ and significance level $\alpha=$ 0,05 is with value equal to 1,664 and at $\alpha=0,01$ obtained value equal to 2,371 . Since t-hitung $=1,984$ and $1,669>$ t-table at $\alpha=0.05$ is 1.664 then $\mathrm{H}_{0}$ is rejected and $\mathrm{H}_{1}$ is accepted, meaning there is significant correlation between teacher leadership in class and guidance approach pattern toward value formation and character in student. While the coefficient of determination $(\mathrm{R} 2)=(\mathrm{r} \mathrm{X} 1 \mathrm{Y}) 2=0.576$, which means there is a contribution of $57.6 \%$ teacher leadership in the class and simultaneous approach to guidance on value and character of the students and the rest of $42.4 \%$ is determined by other factors not examined in this study. So it can be concluded that the leadership of teachers in the classroom and the pattern of guidance approach simultaneously need to be strengthened in order to give effect to increase the formation of value and character of students.

\section{Conclusion}

There is an association between teacher leadership in the classroom towards the formation of the value and character of the students as shown by the positive and significant influencers. The stronger the teacher leadership in the classroom the stronger the building of values and the character of the child is formed. There is a relationship between the pattern of a guidance approach to the building of values and character of the students are shown with a positive and very significant influence. The stronger the pattern of the guidance approach will be the stronger the building of the value and character of the child is formed. There is a link between teacher leadership in the classroom and a simultaneous pattern of guidance approach toward the building of the value and character of the students shown by a positive and significant influence. So the more simultaneous application of teacher leadership in the classroom and the pattern of guidance approach will be done stronger the building of values and character of the child is formed.

\section{Reference}

[1] J. W. Santrock, Educational Psychology. McGraw: Hill Medical Publishing, 2011.

[2] R. Rachmadtullah, Z. Ms, and M. S. Sumantri, "Development of computer - based interactive multimedia : study on learning in elementary education," Int. J. Eng. Technol., vol. 7, no. 4, pp. 2035-2038, 2018.

[3] Susanto and Ratnawati., “'Proses Penerapan Keterampilan Manajemen Kelas dengan Senam Otak dan Pengaruhnya terhadap Kesiapan Belajar dan Hasil Belajar Mata Kuliah Metode Penelitian Mahasiswa Pgsd, Fkip Universitas Esa Unggul, Jakarta.,"” in Proceeding SENDI_U, 2017, p. 821-829.

[4] J. York-Barr and K. Duke, "What Do We Know About Teacher Leadership? Findings From Two Decades of Scholarship," Rev. Educ. Res., vol. 74, no. 3, pp. 255-316, Sep. 2004.

[5] D. Abu, "Prilaku Menyimpang Anak Sekolah Dasar," 2016. [Online]. Available: 
https://www.google.co.id/search?q=darwis + abu + tentang + perilaku + menyimpang + anak + sd\&oq $=\mathrm{d}$ arwis+abu+tentang+perilaku+menyimpang + anak + sd\&gs_l=psy-

ab.3...451646.465269.0.465577.85.62.1.0.0.0.133.4761.50j7.58.0...0...1.1.64.psy-

ab..36.34.2780.6..0j33i21k1j35i39k.

[6] Y. Cheong Cheng, “Teacher Leadership Style: A Classroom-level Study,” J. Educ. Adm., vol. 32, no. 3, pp. 54-71, Sep. 1994.

[7] E. Lai and D. Cheung, "Enacting teacher leadership," Educ. Manag. Adm. Leadersh., vol. 43, no. 5, pp. 673-692, Sep. 2015.

[8] K. S. Cooper, R. N. Stanulis, S. K. Brondyk, E. R. Hamilton, M. Macaluso, and J. A. Meier, "The teacher leadership process: Attempting change within embedded systems," J. Educ. Chang., vol. 17, no. 1, pp. 85-113, Feb. 2016.

[9] K. Leithwood and D. Jantzi, "Principal and Teacher Leadership Effects: A replication," Sch. Leadersh. Manag., vol. 20, no. 4, pp. 415-434, Nov. 2000. 